\title{
Intermezzo in the Rule of Law Play: The Court of Justice's LM Case
}

\author{
Matteo Bonelli
}

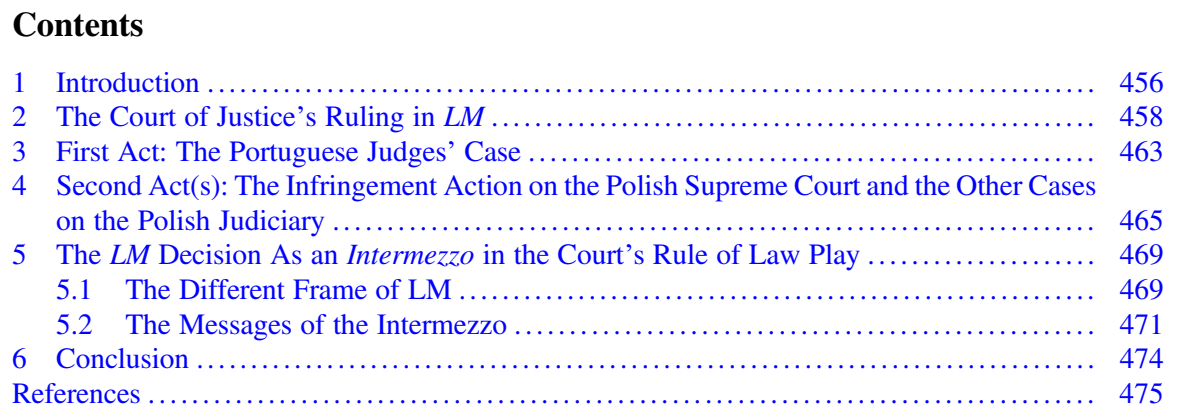

\begin{abstract}
In the $L M$ case, the CJEU was called to decide on whether systemic rule of law deficiencies in Poland could lead to the suspension of EU cooperation based on mutual trust, in particular under the European Arrest Warrant system. Building on its earlier decision in Aranyosi, the Court concluded that EAWs may be suspended only after the executing authority conducts a general analysis of the situation in the country concerned and an individual assessment of the specific situation of the applicant. For some, the decision was a disappointing one, as the Court failed to take a clear stance on the Polish constitutional crisis. This chapter argues, on the other hand, that the Court reached a balanced decision: while it is true that it confirmed the strict Aranyosi test, it also sent some key messages on the crucial importance of the rule of law and judicial independence for the EU and underlined the red lines of European constitutionalism. Furthermore, a different line of cases that originated from the groundbreaking decision of the Court in the 'Portuguese
\end{abstract}

This contribution draws on 'The Deficiencies Judgment: Postponing the Constitutional Moment', Verfassungsblog (27 July 2018) and was finalized in September 2019.

\section{Bonelli ( $ه)$}

Maastricht University, Faculty of Law, Maastricht, The Netherlands

e-mail: matteo.bonelli@maastrichtuniversity.nl 
judges' case seems much more promising for the protection of EU values. Thus, rather than a constitutional moment for the Union, $L M$ was ultimately an intermezzo between the two main acts of the rule of law play before the Court of Justice.

\section{Introduction}

The decision of the Court of Justice in the $L M$ case was one of the most eagerly anticipated of 2018. ${ }^{1}$ The preliminary reference of the Irish High Court brought to the attention of the CJEU two of the thorniest issues of European constitutional law: the EU's reaction to Polish constitutional backsliding ${ }^{2}$ and the operation of the principle of mutual trust, in particular the European Arrest Warrant system (EAW). Many wished the Luxembourg court would take a strong stance on the Polish situation, even suspending the operation of the EAW and possibly other instruments based on mutual trust in Poland. ${ }^{3}$ In any event, the Court of Justice was called to strike an undoubtedly difficult compromise, one bound to be controversial. Unsurprisingly, the ruling delivered on July 25 was welcomed with mixed reactions. ${ }^{4}$ Although generally perceived as a step forward compared to the Opinion of Advocate General Tanchev, ${ }^{5}$ some authors considered the decision of the Court ultimately too timid and insufficient to address the fundamental challenges posed by the Polish judicial reforms. ${ }^{6}$

This contribution takes a different line. First, it argues that, despite some loose ends in its reasoning, the Court's approach and the compromise it reached were ultimately quite solid; ${ }^{7}$ secondly and more broadly, the way in which the $L M$ case was framed was simply not suitable for a bold intervention of the Court in the Polish crisis. ${ }^{8}$ The attempt of Justice Donnelly of the referring Irish High Court to bring to the attention of the Court of Justice her concerns for the Polish rule of law situation was certainly respectable and even courageous. Yet, the line of cases based on Article 19 TEU that initiated with the ruling in the 'Portuguese judges' (or ASJP) case $^{9}$ seems much more promising for the protection of the rule of law and judicial

\footnotetext{
${ }^{1}$ CJEU, Case C-216/18 PPU LM, ECLI:EU:C:2018:586.

${ }^{2}$ See Sadurski (2019) and Pech and Scheppele (2017).

${ }^{3}$ See e.g. von Bogdandy et al. (2018).

${ }^{4}$ For an overview of the first reactions, see the contributions to the Verfassungsblog debate 'The CJEU's Deficiencies Judgment', available at www.verfassungsblog.de/category/themen/aftercelmer/.

${ }^{5}$ CJEU, Case C-216/18 PPU LM, Opinion of Advocate General Tanchev, ECLI:EU:C:2018:517.

${ }^{6}$ See e.g. Bard and van Ballegooij (2018), Krajewski (2018) and Scheppele (2018).

${ }^{7}$ On the 'elegant compromise' reached by the Court, see also Sonnevend (2018).

${ }^{8}$ For a similar argument, see Kosar (2018), who argued that 'neither the preliminary reference procedure nor the fundamental right to the fair trial are good 'vehicles' for addressing the Polish structural judicial reforms'.
}

${ }^{9}$ CJEU, Case C-64/14 Associação Sindical dos Juízes Portugueses, ECLI:EU:C:2018:117. 
independence in Poland and across the Union. The landmark ruling of the Court of Justice in the infringement action on the reform of the Polish Supreme Court ${ }^{10}$ very well demonstrates the potential of this new approach to Article 19 TEU and offered a perfect moment for the Court of Justice to finally enforce the red lines of European constitutionalism. ${ }^{11}$ Further opportunities to advance this line of cases will come in the next months: a second infringement action, ${ }^{12}$ as well as a series of preliminary references coming from Polish courts, ${ }^{13}$ are now pending in Luxembourg.

All considered, rather than a decisive moment of the Court of Justice's rule of law play, ${ }^{14}$ the $L M$ case could be best seen as an intermezzo between the two key acts: the 'Portuguese judges' decision, in which the Court, offering an extensive interpretation of Article $19 \mathrm{TEU}$, set the scene for its intervention; and then the infringement procedure on the Supreme Court, as well as the other forthcoming rulings on the Polish judiciary, in which the Court took the next step and began enforcing the EU judicial independence standards. At the same time, it should not be forgotten that it is unlikely that legal mechanisms alone could address crises such as the Polish or the Hungarian ones. The procedures under Article 7 TEU against both Member States might prove equally, if not more, important than the Court's decisions, and the Court itself seems to be aware of the importance of political mechanisms.

The chapter develops these points in the following paragraphs, starting from a brief analysis of the $L M$ case (Sect. 2), then taking a step back to the 'Portuguese judges' case (Sect. 3) and one forward to the Article 19 cases on the Polish judiciary and in particular the infringement action on the Supreme Court (Sect. 4). Having done so, the contribution explains why $L M$ can therefore be best seen as an intermezzo in the Court's play (Sect. 5): the framing of the case did not offer to the Court the best opportunity for a strong intervention in the Polish constitutional crisis. Nonetheless, the Court still sent some clear messages to Polish authorities and the European public, making it clear that European constitutionalism contains red lines against threats to democracy and the rule of law. Furthermore, the Court

\footnotetext{
${ }^{10}$ CJEU, Case C-619/18 Commission v. Poland (Supreme Court), ECLI:EU:C:2019:53. See also the two previous interim orders: CJEU, Case C-619/18 Commission v. Poland, Order of 19/10/ 2018, ECLI:EU:C:2018:852 and Order of 17/12/2018, ECLI:EU:C:2018:1021.

${ }^{11}$ On red lines, von Bogdandy et al. (2018).

${ }^{12}$ See CJEU, Case C-192/18 Commission v. Poland (Law on the Organisation of Ordinary Courts) (pending), and the Opinion of Advocate General Tanchev in the same case. In July 2019, the Commission has also opened another infringement action regarding the new disciplinary regime for Polish judges: see European Commission, Press Release-Rule of Law: European Commission takes new step to protect judges in Poland against political control, Brussels, 17 July 2019. The case was decided in November 2019, after the submission of this contribution.

${ }^{13}$ See Opinion of Advocate General Tanchev in Joined Cases C-585/18, C-624/18 and C-625/18 A. K. (C-585/18) v Krajowa Rada Sadownictwa and CP (C-624/18) DO (C-625/18) v Sad Najwyższy (C-624/18 and $C$-625/18), ECLI:EU:C:2019:551. These joined cases were also decided in November 2019, after the submission of this contribution.

${ }^{14}$ Even more drastically, Avbelj (2018) concluded that the Celmer case was not 'a landmark ruling' and that its impact will not be 'of seismic constitutional proportions'.
} 
restated the need for parallel political procedures that can give further bite to the red lines.

\section{The Court of Justice's Ruling in $L M$}

As described in other contributions to this volume, the $L M$ case originated in Ireland, where the High Court was called to give execution to a EAW issued by Poland against Mr. Artur Celmer, accused of drug-related offences. The Irish Court doubted whether, in view of the systemic deficiencies with the rule of law in Poland, the execution of the EAW could lead to the violation of the applicant's fundamental right to a fair trial, protected by the Irish Constitution, the ECHR and the EU Charter of Fundamental Rights. It is worth underlining a few key elements of the Irish High Court's referral, in order to illustrate how the latter framed the case and how this influenced the proceedings before the Court of Justice.

Generally and most importantly, the Irish Court built its questions on the basis of the previous Aranyosi decision of the Court of Justice. ${ }^{15}$ In this landmark case, the CJEU acknowledged for the first time that the execution of EAWs could be suspended in case of systemic deficiencies in the issuing Member State. Following the Aranyosi approach, the Irish Court in the first place directly assumed the existence of systemic rule of law problems in Poland and did not call the CJEU to reflect on that matter. ${ }^{16}$ In Aranyosi, in fact, the CJEU left to the referring court to determine whether the deficits of prisons facilities in Hungary and Romania amounted to a systemic problem. ${ }^{17}$ Second, the Irish Court brought to the attention of the Court the position of the specific individual concerned by the surrender request and his fundamental right to a fair trial. This is to say that the referring court wanted to understand what would be the effects of the assumed breach of the common values on the specific situation of the applicant, and in particular whether they could amount to a 'flagrant denial of justice' for the individual. ${ }^{18}$ Third, the Irish

\footnotetext{
${ }^{15}$ CJEU, Case C-404/15 Aranyosi and Câldâraru, ECLI:EU:C:2016:198.

${ }^{16}$ Irish High Court, The Minister for Justice and Equality and Artur Celmer, Record no. 2013 EXT 295, 12 March 2018, para. 123: the Commission reasoned that a proposal under Art. 7 is considered a 'shocking indictment of the status of the rule of law', illustrating 'what appears to be the deliberated, calculated and provocative legislative dismantling by Poland of the independence of the judiciary. In the next paragraph, the Irish High Court then 'concludes ... that the rule of law in Poland has been systematically damaged' and further adds (para. 135) that 'the common value of the rule of law in Poland has been breached'.

${ }^{17}$ See also the Opinion AG Tanchev in Celmer, supra note 5, para. 35: 'it is not for the Court to rule on whether there is a real risk of breach of the right to a fair trial on account on deficiencies in the Polish system of justice ... It is for the executing judicial authority to rule on the existence of such a risk'.

${ }^{18}$ Irish High Court, The Minister for Justice and Equality and Artur Celmer, supra note 16, para. 137. On flagrant denial of justice, see para. 107: it constitutes the standard for extradition cases both under Irish law and under the ECHR.
} 
Court asked a very specific question to the Court of Justice, all imprinted on the applicability of the Aranyosi test and in particular of its second prong, namely the individual part of the test. ${ }^{19}$ While the Irish judge considered conducting an individual test 'unrealistic' and 'difficult' in the situation she was confronted with, ${ }^{20}$ it was precisely on this matter - the necessity to conduct an individual test even after establishing the existence of a systemic problem-that the Court of Justice was called to intervene and clarify the landscape. The answers given by the Advocate General and the Court of Justice were thus necessarily informed by the referring courts' questions and analysis, as it is true for any preliminary reference to the CJEU under Article 267 TFEU.

In substance, Advocate General Tanchev and the Court of Justice reached similar conclusions, confirming the applicability of both prongs of the Aranyosi test: an individual assessment of the specific situation of the applicant is required after establishing that the situation amounts to a systemic threat to the rule of law, which has negative repercussions on Article 47 of the Charter protecting the fundamental right to a fair trial. ${ }^{21}$ Yet, the overall approach and tone of the Advocate General and the Court were not identical. The Advocate General's Opinion considered the possibility of refusing to execute the EAW absolutely exceptional. More precisely, Advocate General Tanchev argued that not any breach of Article 47 of the Charter could lead to postpone the execution of an EAW. Postponement, in his view, would only be possible when 'there is a real risk that [the individual] will be exposed in the issuing Member State to a flagrant denial of justice,; ${ }^{22}$ in turn, problems with the independence and impartiality of a court could only amount to a flagrant denial of justice when they '[destroyed] the fairness of the trial'. ${ }^{23}$ While the Opinion argued that it should be left to the referring court to determine whether the Polish situation reached that level, it established an extremely high threshold already for the first, general part of the Aranyosi test.

The ruling of the Grand Chamber of the Court of Justice, while fairly similar in the operative part-confirming in particular the need for the individualized assessment, the second prong of the Aranyosi test-showed more explicitly the judges' concerns with the Polish situation. Overall, the Court's reasoning and the underlying tone are more convincing. Both in the specific response to the referring court and in the message sent to the European public eagerly waiting for the decision, the Court tried to find a balance between, on the one hand, emphasizing the importance of the

\footnotetext{
${ }^{19}$ Irish High Court, The Minister for Justice and Equality and Artur Celmer, supra note 16, see para. 145. The second question is on a more specific aspect of the individual prong, namely whether the referring court has to contact the issuing judicial authority in order to obtain further necessary information.

${ }^{20}$ Irish High Court, The Minister for Justice and Equality and Artur Celmer, supra note 16, paras. 141 and 142.

${ }^{21}$ This was also the view expressed by the Commission in the case: see Opinion AG Tanchev in Celmer, supra note 5, para. 103.

${ }^{22}$ Opinion AG Tanchev in Celmer, supra note 5, para. 69.

${ }^{23}$ Opinion AG Tanchev in Celmer, supra note 5, para. 93.
} 
common values of the rule of law and fundamental rights for the Union as a whole and, on the other, protecting the smooth operation of mutual trust instruments. The Court reached that balance using different languages and techniques.

On the one hand, the Court reinstated some of its traditional mutual trust arguments. ${ }^{24}$ By making a textbook reference to Opinion $2 / 13,{ }^{25}$ the Court repeated that mutual trust is a principle of fundamental importance for the Union's legal order that can only cease to operate in 'exceptional cases' ${ }^{26}$ As a rule, judicial authorities are thus 'require[d] to execute any European arrest warrant on the basis of the principle of mutual recognition'; refusals are, on the other hand, exceptions 'which must be interpreted strictly'. ${ }^{27}$ The crucial importance of the principles of mutual trust and mutual recognition led the Court to confirm the need for the individual assessment of the specific situation of the applicant, which remains necessary even after establishing the existence of a systemic problem. At the same time, in $L M$, for the first time, the Court extended the Aranyosi approach to a non-absolute right such as the right to a fair trial. Furthermore, it lowered the strict requirements posited by the Advocate General, ${ }^{28}$ and generally granted a broad discretion to the executing authorities in conducting both parts of the assessment. In particular, the Court left to the executing authority the task to evaluate whether the possible systemic deficiencies generated a real risk to the fundamental right to a fair trial ${ }^{29}$ and only made general references to the facts to be considered in conducting the second part of the assessment, which include the personal situation of the applicant, the 'nature of the offence', and the 'factual context' in which the EAW was issued. ${ }^{30}$ National authorities are thus granted a wide margin of action in taking their final decision on the execution of the warrant and they could easily play with the Court's criteria in order to justify a possible suspension of cooperation. ${ }^{31}$

The Court then went even a step further. Several paragraphs of the rulings can be read as implicit messages that the Court considers the Polish situation deeply problematic. The first message is the importance given to the concept of judicial independence, a point on which the Court departs from the approach of the Advocate General. The Opinion had indeed considered that problems with judicial independence could amount to a 'flagrant denial of justice' only when they radically destroyed the fairness on the trial. The Court thinks differently. It held that judicial

\footnotetext{
${ }^{24} \mathrm{CJEU}$, LM, supra note 1 , see paras. 35-37.

${ }^{25} \mathrm{CJEU}$, Opinion 2/13 Accession of the EU to the ECHR, ECLI:EU:C:2014:2454, in particular para. 192.

${ }^{26} \mathrm{CJEU}$, LM, supra note 1, para. 37.

${ }^{27} \mathrm{CJEU}$, LM, supra note 1, para. 41.

${ }^{28}$ See also Konstadinides (2019), p. 745.

${ }^{29} \mathrm{CJEU}$, LM, supra note 1, para. 61.

${ }^{30} \mathrm{CJEU}$, LM, supra note 1, para. 75.

${ }^{31}$ It is not be noted, however, that the Irish High Court ultimately did not suspend the transfer: Irish High Court The Minister for Justice and Equality v. Celmer No. 5, Record no. 2018 IEHC 639, 19 November 2018. The decision has been appealed in the meantime.
} 
independence 'forms part of the essence of the fundamental rights to a fair trial', 32 which seems to mean that any breach of that requirement should be considered a breach of the essence of Article 47 of the Charter, thus in principle able to lead to the suspension of a EAW transfer, following the two steps of the assessment. Moreover, with references in particular to the cases ASJP, Wilson, ${ }^{33}$ and $T D C,{ }^{34}$ the Court summarized its case law setting the EU law requirements of judicial independence and generally pointed at the crucial relevance of judicial independence for the Union constitutional order. ${ }^{35}$ Crucially, independence is one of the conditions for participation to the preliminary reference system, the 'keystone' ${ }^{36}$ of the EU judicial system: the Court of Justice has since long maintained that only 'independent' bodies can send preliminary questions to the Court of Justice under Article 267 TFEU.

The Court sent a second signal in paragraph 61 of the ruling, where it gave instructions to the referring court on the materials to be evaluated in determining the existence of systemic deficiencies (the first part of the Aranyosi test). ${ }^{37}$ The Court affirmed that the Commission's reasoned proposal under Article 7(1) TEU 'is particularly relevant' for that assessment. When taking also into account the long summary of the Commission's document in the first part of the ruling, ${ }^{38}$ it becomes evident that the Court wanted to underline the importance of the document adopted by the Commission, suggesting that the concerns expressed by the Commission are at least well founded. All in all, the Court's analysis strived to find a delicate balance: protecting the smooth functioning of mutual trust and thus of the European legal order, while remarking that the rule of law and judicial independence are of the outmost importance for the EU. In doing so, the Court further bolstered the expectations for its following rulings on the Polish judiciary, discussed later in this contribution. $^{39}$

Nonetheless, as already mentioned above, the decision was not universally praised. There are two main strands of criticism. The first concentrates on the feasibility of conducting an individual assessment in cases where judicial independence is at stake. ${ }^{40}$ The task of the executing judicial authority, it is said, is excessively complex, especially because it cannot truly rely on the authorities of the issuing Member State, as they are the direct targets of the reforms in question and may thus have a stake in the process. The second strand of criticism, on the other hand, looks at $L M$ and at the Court's approach mostly as a missed opportunity in the

\footnotetext{
${ }^{32}$ CJEU, LM, supra note 1, para. 48.

${ }^{33} \mathrm{CJEU}$, Case C-506/04 Wilson, ECLI:EU:C:2006:587.

${ }^{34}$ CJEU, Case C-22/13 TDC, ECLI:EU:C:2014:2265.

${ }^{35} \mathrm{CJEU}$, LM, supra note 1, paras. 63-67.

${ }^{36}$ CJEU, Case C-284/16 Achmea, ECLI:EU:C:2018:158.

${ }^{37} \mathrm{CJEU}$, LM, supra note 1 , para. 61 .

${ }^{38} \mathrm{CJEU}, L M$, supra note 1 , paras. $18-21$.

${ }^{39}$ See Sect. 4.

${ }^{40}$ See e.g. Bard and van Ballegooij (2018).
} 
rule of law play. ${ }^{41}$ It is said, for example, that by sticking to the question referred and thus focusing on the individual fundamental right to a fair trial, rather than on the rule of law in general, the Court failed to take a clearer stance against Polish constitutional backsliding.

There is certainly some truth in both assertions. The individual assessment national courts are called to do is much more complex than the already difficult analysis they were asked to pursue in the Aranyosi situation. ${ }^{42}$ While evaluating the fundamental rights' conditions of specific detention centers is, although not easy, still feasible-and the Court of Justice has further helped to clarify the procedure ${ }^{43}$ _assessing whether a trial could be fair, despite the structural changes to a rule of law regime, is a much more difficult and speculative exercise. It demands that judges try to grasp and assess the functioning of other legal orders they are not necessarily familiar with. ${ }^{44}$ There is also a higher risk of receiving conflicting information and that the authorities to which clarifications are asked are already compromised, i.e. not independent. The Court perhaps downplayed the difficulties in applying the Aranyosi test to a different context. Offering more guidance to national courts could have been an option to pursue-for example further clarifying the factors to be taken into account for the individual assessment-but the Court preferred to follow the opposite approach, namely granting them a wide margin of discretion, which may also be used for refusing surrenders when issuing authorities do not give sufficient assurances on the individual trial.

As for the 'missed opportunity' critique, the Court of Justice could certainly have been more explicit in pointing out the systemic threats to the rule of law in Poland, as it did for example in N.S. on the systemic problems of the Greek asylum system. ${ }^{45}$ Furthermore, there is no doubt that a more centralized system of assessment at least of the 'systemic' part of the test would certainly have significant benefits. ${ }^{46} \mathrm{How}$ ever, that was not the issue the Irish Court referred to Luxembourg: the questions concentrated on the applicability of the second part of the Aranyosi test. More generally, the task of the Court in preliminary references, according to Article 267 TFEU, is to rule on the interpretation and validity of EU law, not to assess the factual situation in a Member State. While the Court has always interpreted its powers under Article 267 TFEU in a fairly broad manner, ${ }^{47}$ it remains that there are limits to what it can do in the context of a preliminary reference.

\footnotetext{
${ }^{41}$ See Krajewski (2018), Pech and Wachowiec (2018), Scheppele (2018) and Wendel (2019).

${ }^{42}$ On the complexity of the test, see Lazowski (2018), p. 14.

${ }^{43}$ See CJEU, Case C-220/18 PPU Conditions de détention en Hongrie, ECLI:EU:C:2018:589.

${ }^{44}$ On this difficulty, see Krajewski (2018) and Konstadinides (2019).

${ }^{45}$ CJEU, Joined Cases C-411/10 and C-493/10, N.S. and Others, ECLI:EU:C:2011:865. In N.S. the Court found that systemic problems in the asylum system of a Member State, creating a real risk of inhuman or degrading treatment, prevent asylum transfers under the Dublin regulation. An individual assessment of the specific situation of the applicant is not necessary in those circumstances.

${ }^{46}$ See Wendel (2019).

${ }^{47}$ In general, see Broberg and Fenger (2014).
} 
Hence, the framing of the case did not offer the best opportunity for the Court to take a clear stance on the Polish crisis. Rather than a sign of a timid approach of Luxembourg towards cases of constitutional backsliding, the decision can be best seen as an intermezzo in the Court's rule of law play, which took place between the two main acts: the ruling in the 'Portuguese judges' and then a set of more precise and targeted decisions on the Polish situation, which has started with the key ruling in the Supreme Court case. To better understand $L M$, thus, it seems necessary to, first, take a step back and look at the decision in Associação Sindical dos Juizes Portugueses, and then a step forward, analyzing the 'Supreme Court' ruling and then the other forthcoming decisions on the Polish judiciary, mapping out the different contexts in which these other decisions have been and will be taken.

\section{First Act: The Portuguese Judges' Case $^{48}$}

In contrast to $L M$, the 'Portuguese judges' case was far less anticipated and much more surprising. Rather than a rule of law case, it seemed to fall in the Court's line of 'austerity cases': ${ }^{49}$ a group of Portuguese judges complained that austerity measures reducing their salaries, adopted in order to comply with the demands of the Memoranda of Understanding signed in the context of ESM financial assistance programmes, violated the principle of judicial independence guaranteed by Article 19 TEU and 47 of the Charter. It is only from this austerity perspective that interest in the case was growing, ${ }^{50}$ especially after the Opinion of the Advocate General, who argued for the applicability of the Charter to ESM-related measures. ${ }^{51}$

The Court followed however a different path. It remained silent on the applicability of the Charter to ESM-related austerity measures and transformed the austerity case into a 'constitutional backsliding' or rule of law one. It did so by relying on Article 19 TEU, significantly bolstering both its scope of application and its substantive content. First, the Court read in a broad manner the expression 'the fields covered by Union law' that is used in Article 19 TEU (second sentence: 'Member

\footnotetext{
${ }^{48}$ This section draws on Bonelli and Claes (2018).

${ }^{49}$ See for example the other Portuguese cases CJEU, Order in Case C-128/12, Sindicato dos Bancários do Norte and Others v. BPN_Banco Português de Negócios SA, ECLI:EU: C:2013:149; Order in Case C-264/12 Sindicato Nacional dos Profissionais de Seguros e Afins v. Fidelidade Mundial-Companhia de Seguros SA, ECLI:EU:C:2014:2036; Order in Case C-665/13 Sindicato Nacional dos Profissionais de Seguros e Afins v. Via Directa-Companhia de Seguros SA, ECLI:EU:C:2014:2327.

${ }^{50}$ After a long period in which the Court showed reluctance to engage in judicial review of national austerity measures, the orientation of the Court partially shifted in the Ledra (CJEU, C-8/15 P Ledra Advertising, ECLI:EU:C:2016:701) and Florescu (CJEU, C-258/14 Florescu, ECLI:EU: C:2017:448), and some expected Luxembourg to extend the Florescu reasoning on the applicability of the Charter to national austerity measures implementing EU-related Memoranda of Understanding to the ESM context: see Markakis and Dermine (2018).

${ }^{51}$ See CJEU, Opinion of Advocate General Øe in C-64/16 ASJP, ECLI:EU:C:2017:395.
} 
States shall provide remedies sufficient to ensure effective legal protection in the fields covered by Union law') and created a new 'sphere' of Union law. According to the Luxembourg Court, Article 19 TEU has a broader scope of application than the rest of Union law including the Charter. It brings under the purview of the Court situations that would otherwise fall outside the scope of Union law, because they are not linked to any EU substantive competence. ${ }^{52}$ Second, the Court read Article 19 TEU as containing an obligation to ensure the judicial independence of national courts acting in the fields covered by EU law, despite the absence of any textual reference to the concept of judicial independence in the provision. By doing so, the Court de facto aligned the substantive content of Article 19 TEU with that of Article 47 of the Charter, which includes the right to an independent court. This broad reasoning allows the Court of Justice to assess against EU standards any national measure that affects the judicial independence of courts or tribunals acting in the fields covered by Union law, that is, the vast majority of the national judiciary.

While formally being about Portuguese judges and austerity measures, much in the ruling suggests that the Court had actually in mind the Polish situation. The Court wanted to get a say in the judiciary reforms pushed forward by Law and Justice. Yet, on a traditional reading, these reforms could be considered as falling outside the scope of EU law. In order to bring the reforms under its purview, the Court needed therefore to significantly stretch the reach of EU law and of the principle of judicial independence, and did so by reading Article 19 TEU in the expansive manner just described.

The setting of $A S J P$ was thus the following: a preliminary reference challenging the compatibility with EU law, and more precisely with the principle of judicial independence guaranteed by Article 19 TEU, of specific domestic measures, namely the salary cuts adopted to implement the Memorandum of Understanding between the EU and Portugal. The Court was not truly concerned with the Portuguese measures under discussion, though, and quickly dismissed the arguments brought by the group of Portuguese judges ${ }^{53}$ Rather, the Court took the opportunity to prepare the ground for a more direct intervention in the Polish crisis. The 'Portuguese judges' case, delivered in February 2018, served as an invitation for the Commission to pursue infringement actions based on Article 19 TEU on controversial aspects of the Polish judicial reforms. The Commission accepted the invitation a few months later, in July, opening an action against the Supreme Court reform ${ }^{54}$ and quickly bringing it to Luxembourg. On the other hand, there was no clear connection between $A S J P$ and the $L M$ situation, which originated in a completely different context (mutual trust obligations), focused on the interpretation of provisions other than Article 19 TEU, and ultimately asked the Court of Justice to conduct another

\footnotetext{
${ }^{52}$ See Bonelli and Claes (2018), p. 631. The new sphere is thus a 'functional' one: the key factor for falling under the jurisdiction of the Court is not whether the circumstances of the case touch upon matters regulated by Union law, but the function of national courts as part of the European judiciary. ${ }^{53} \mathrm{CJEU}$, ASJP, supra note 9, paras. 46-51.

${ }^{54}$ European Commission, Press Release: Rule of Law: Commission launches infringement procedure to protect the independence of the Polish Supreme Court, Brussels, 2 July 2018, Doc. IP/18/ 4341.
} 
type of assessment. The true next step in the rule of law line of cases, thus, was not $L M$, but the infringement action on the Polish Supreme Court's reform, as will be pointed out in the next section.

\section{Second Act(s): The Infringement Action on the Polish Supreme Court and the Other Cases on the Polish Judiciary}

As noted in the previous section, the Commission almost immediately followed the 'invitation' of the Court to tackle the controversial Polish reforms through Article 19 TEU and opened an infringement procedure on the Law on the Supreme Court. After two crucial interim orders delivered in the last months of 2018, the Court of Justice decided the case in June 2019, ultimately finding a violation of the second subparagraph of Article 19(1) TEU. Before explaining how the Court approached the case, it seems however appropriate to briefly recall how the Commission had been tackling the Polish crisis up until the ASJP decision.

At first, the Commission reacted to the controversies surrounding the composition and functioning of the Polish Constitutional Tribunal by activating the 'Rule of Law Framework'. The instrument, which is a base for political dialogue between the Commission and Polish authorities, did not produce adequate results; on the contrary, after completing the capture of the Constitutional Tribunal, the 'Law and Justice' majority began to reform the other institutions of the judiciary: ordinary courts, the Supreme Court, and the National Council of the Judiciary. After three unsuccessful Rule of Law Recommendations issued under the Framework, the Commission finally decided to move to the next step in December 2017, activating for the first time in EU history Article 7(1) TEU. ${ }^{55}$

Furthermore, already in July 2017, the Commission had launched a first infringement action on the Law on Ordinary Courts, questioning the compatibility with EU law of the reform under two profiles in particular. First, the Commission alleged that the new norms on the judges' retirement age were not compatible with EU gender equality law, as they provided different retirement ages for male and female judges. This first point of contention bore clear similarities with an earlier infringement action on the Hungarian judiciary reforms, which, despite the Commission's victory in Luxembourg, ${ }^{56}$ had however not prevented Fidesz's takeover of the judiciary. ${ }^{57}$ The Commission, aware that a purely technical, 'indirect" ${ }^{58}$ infringement action

\footnotetext{
${ }^{55}$ European Commission, Reasoned Proposal in Accordance with Article 7(1) of the Treaty on European Union Regarding the Rule of Law in Poland, Brussels, 20 December 2017, Doc. COM (2017) 835 final.

${ }^{56}$ See CJEU, Case C-286/12 Commission v. Hungary, ECLI:EU:C:2012:687.

${ }^{57}$ See e.g. Belavusau (2013) and Halmai (2017).

${ }^{58}$ Dawson and Muir (2013).
} 
could not work, raised also a second point: it argued that the discretionary powers assigned to the Ministry of Justice on the prolongation of the judges' mandates and on the appointment and dismissal of courts' presidents undermined the independence of the Polish judiciary under Article 19(1) TEU and Article 47 of the Charter. This second argument added thus an important layer to the Commission's action under Article 258 TFEU and it was one of the first times in which Article 19(1) TEU was mentioned as a possible source of rule of law obligations. The infringement action was then referred to the Court in December 2017 and was still pending at the time of writing.

This is the context in which the 'Portuguese judges' decision arrived. The decision supported the Commission's reliance, in the infringement action on the Ordinary Courts, on Article 19 TEU as a tool to protect judicial independence. The Court agreed that Article 19 TEU is a 'concrete expression' ${ }^{59}$ of the value of the rule of law and contains a principle of judicial independence. But in ASJP the Court of Justice went even a step further, extending the scope of Article 19 to all national courts acting in the fields covered by Union law. If the infringement action on the ordinary court could still be re-conducted to the ordinary scope of EU law, as the reform was allegedly in conflict with EU anti-discrimination law, the broad reading of Article 19 TEU in ASJP liberated the Commission from the need of finding a hook in an infringement of EU substantive law, which could bring with it the application of the Charter and of its Article 47. In plain words, after the ASJP decision, the Commission may start a new infringement action for an alleged violation of the principle of judicial independence purely on the basis of Article 19 TEU.

This is precisely what the Commission did in July 2018, starting an Article 258 procedure on the reform of the Supreme Court, after the entry into force of the Polish law imposing the anticipated retirement of the Supreme Court's judges and following the growing controversies on the mandate of the President of the Court. ${ }^{60}$ In this new procedure, the Commission did not refer to any alleged breach of substantive EU law. It only relied on Article 19 TEU and, more surprisingly, on Article 47 of the Charter, which however did not seem applicable to the situation at stake as it did not constitute an implementation of EU law. ${ }^{61}$ The Commission then referred the case to the Court in September 2018, asking for interim measures and the application of the urgent procedure. ${ }^{62}$

\footnotetext{
${ }^{59} \mathrm{CJEU}$, ASJP, supra note 9, para. 32.

${ }^{60}$ European Commission, Press Release: Rule of Law: Commission launches infringement procedure to protect the independence of the Polish Supreme Court, Brussels, 2 July 2018, Doc. IP/18/ 4341.

${ }^{61}$ As will be explained in the next paragraphs, the Court of Justice-as also suggested by Advocate General Tanchev-ultimately assessed the contested norms only on the basis of Article 19 TEU, though it did not explicitly state that Art. 47 of the Charter was not applicable in the case.

${ }^{62}$ European Commission, Press Release-European Commission refers Poland to the European Court of Justice to protect the independence of the Polish Supreme Court, Brussels, 24 September 2018, IP/18/5830.
} 
The infringement actions launched by the Commission-both the Supreme Court one and the earlier action on the Law on Ordinary Courts-follow the Court's approach in ASJP much more evidently than LM. First, the key provision in both actions is Article 19 TEU, as it was in ASJP. Second, while of course the concrete situations are radically different-austerity measures reducing judges' salaries, in $A S J P$, and a full-scale reform of the judiciary in the Polish cases-the Court is asked to conduct a similar exercise, namely to assess whether the national laws in question conflict with the EU principle of judicial independence. In the infringement actions, the Court can do so explicitly and can reach a final decision on whether or not Poland has failed to fulfill its obligations under the Treaties; in the ASJP case, a preliminary reference, the Luxembourg Court did not have the competence to assess the measures directly, but still it made clear that EU law does not preclude measures such as those at issue in the proceedings. The similarities between the two settings suggest that what the Court had in mind when it delivered the ASJP decision was precisely an action framed like the Supreme Court's infringement procedure.

The Court of Justice's willingness to forcefully intervene in the Polish crisis was confirmed in its two interim orders as well as in the final ruling. ${ }^{63}$ In the first order, delivered by the Vice President of the Court inaudita altera parte on the basis of Article 160(7) of the Court of Justice Rules of Procedure, the Commission's requests were all satisfied. The Vice President asked Polish authorities to suspend the application of judges' retirement measures, allow the judges to carry out their duties in the same position, and refrain from nominating new judges to the Supreme Court. Remarkably, the interim order was meant to be retroactive and self-implementing: the request to Polish authorities was not to reinstate the judges, but to suspend the application of the law ex tunc and thus to consider that the retirement measures had never applied to them. In the second interim order, the Court confirmed, after hearing the Polish authorities, the same requests. Polish authorities were asked to restore the situation as it stood before the approval of the reform and to refrain from adopting any measure that could have interfered with the final decision of the Court of Justice.

As was to be expected after the interim orders, the final decision of June 2019 found a violation of EU law obligations by Poland. In its ruling, the Court of Justice first reaffirmed its jurisdiction to assess the national measures in question, stating that, while the organisation of justice is a competence of the Member States, 'when exercising that competence, the Member States are required to comply with their obligations deriving from EU law, ${ }^{64}$ and thus crucially with the obligation to guarantee judicial independence under Article 19 TEU. ${ }^{65}$ In substance, the Court accepted both complaints presented by the Commission, the first related to the principle of irremovability of the judges, which was violated by the measures lowering retirement age, ${ }^{66}$ and the second concerning the 'external' independence

\footnotetext{
${ }^{63}$ See supra.

${ }^{64}$ Para. 52.

${ }^{65}$ Paras. 55 and 57.

${ }^{66}$ See paras. 71-97.
} 
of the judges of the Supreme Court, breached by the decision to assign to the President of the Republic the power to decide on the extension of the judges' mandate. $^{67}$

Compared to the earlier infringement action against Hungary mentioned earlier, the action of the Commission and the ruling of the Court have sharper effects. In the Hungarian case, national authorities were simply asked to offer to the judges concerned an alternative between compensation and reinstatement, with no guarantee that they could return to the same position. Fidesz was thus still able to remove the undesired judges and replace them with more loyal personnel. ${ }^{68}$ In the Polish action, on the other hand, the Court of Justice put more far-reaching obligations on national authorities, already in the two interim orders. In simple words, the reform of the Supreme Court had to be reversed, and the judges of the Supreme Court allowed to continue their mandates. The Polish authorities well understood that they had little alternatives, if they wanted to avoid a full-scale confrontation with the Court of Justice and the EU institutions, as well as a possible penalty payment under Article 260 TFEU, had they refused to implement the orders ${ }^{69}$ and the final judgement. Even before the final judgment of the Court, the Polish Parliament passed a new law in November 2018, repealing the previous reforms, and the law was then promulgated by the President of the Republic in December, just after the second order of the Court of Justice.

Infringement procedures based on a violation of Article 19 TEU seem therefore to be an excellent framework for the Court's intervention in rule of law crises. Both in its order and in the final ruling, the Court of Justice has demonstrated a certain readiness and willingness to intervene forcefully and to read its powers in a broad manner: in substance, the extensive reading of the scope of Article 19 TEU has been confirmed; procedurally, the Court delivered a rather exceptional order, even before the formal hearing, and requested far-reaching interim measures. What is more, the Supreme Court infringement action is not an isolated decision, and the Court of Justice will have other chances to continue developing its jurisprudence on Article 19 TEU and judicial independence. One opportunity was the other infringement action pursued by the Commission on the Law on Ordinary Courts, although Polish authorities had already modified the regime of appointment and dismissal of courts' presidents. Then, there are the several preliminary references sent by Polish courts themselves questioning the compatibility of parts of the Polish reforms with EU law. ${ }^{70}$ But of course the new approach to Article 19 TEU can become relevant also

\footnotetext{
${ }^{67}$ See paras. $108-124$.

${ }^{68}$ The action was considered an instance of 'symbolic' compliance: see Batory (2016).

${ }^{69}$ The possibility to impose penalty payments in case of non-compliance with an order of the Court was affirmed in another case concerning Poland, but unrelated to the judiciary reforms: CJEU, C441/17 Commission v. Poland, ECLI:EU:C:2018:255.

${ }^{70}$ For an analysis, see Biernat and Kawczyńska (2018).
} 
for other cases including the new Hungarian reform of administrative justice ${ }^{71}$ and possibly the Romanian reforms of the judiciary. ${ }^{72}$

\section{The LM Decision As an Intermezzo in the Court's Rule of Law Play}

The next paragraphs return to $L M$ and explain why it should be considered as an intermezzo in the Court's rule of law play, rather than a key constitutional moment for the Union. Most importantly, the framing of the case was ultimately not a suitable platform for a strong intervention in the Polish crisis by the Court. Nonetheless, the intermezzo was not unrelated to the previous and following acts: the Court still sent a few important messages, showing its concerns with the rule of law situation in Poland and in the continent at large. Finally, the LM's intermezzo served also to restate the need for parallel political procedures that can give further bite to the red lines of European constitutionalism.

\subsection{The Different Frame of LM}

In the first place, it is crucial to recall the perspective through which the $L M$ case reached the Court. The gist of the case was the protection of a specific fundamental right (Article 47 of the Charter) of a specific individual (Artur Celmer) and the interpretation of the EAW Framework Decision. On the other hand, the case did not concern - at least directly - the legislative changes operated by the Polish Parliament and generally the rule of law situation in Poland. ${ }^{73}$ Of course, there were crucial connections between these two facets, but the fact remains that the applicant and the referring court asked to the Court of Justice precisely to reflect on how the general rule of law situation in Poland reflected on the individual position of the applicant and on his right to a fair trial. The Irish Court was only interested in the question of Mr. Celmer's possible surrender. Thus, the substantive situation, i.e. the reforms undertook by the Polish government, while certainly crucial as context and background of the decision, were not the core concern of the Court of Justice. On the other hand, in the infringement procedure on the Supreme Court and the other cases

\footnotetext{
${ }^{71}$ See Uitz (2019).

${ }^{72}$ See e.g. the preliminary reference sent by a Romanian Court in January 2019 on the obligations deriving from the Commission's Recommendations under the Cooperation and Verification Mechanism and from Art. 19 TEU: www.hotnews.ro/stiri-esential-22941400-decizia-fara-precedentunei-instante-din-romania-curtea-justitie-uniunii-europene-solicitata-spuna-daca-autoritatile-bucu resti-sunt-obligate-respecte-recomandarile-din-mcv.htm.

${ }^{73}$ See also Konstadinides (2019), p. 751.
} 
mentioned above, the key concern of the Court is whether the Polish legislation complies with Article 19 TEU and the requirement of judicial independence. In other words, the Court in these cases concentrates on the value of the rule of law as 'specified' by Article 19 TEU. Furthermore, in this second set of cases there are no conflicting interests to be safeguarded, such as protecting mutual trust, the smooth functioning of the EAW and generally the effectiveness of EU law.

The differences between the two settings can also be outlined with reference to the consequences and effects of the rulings. A good exercise is imagining what would have happened, if the Court had reached a bolder conclusion in $L M$, perhaps generally suspending the application of the EAW system vis-à-vis Poland. First, the decision would have created a high risk of impunity in the Union's Area of Freedom, Security and Justice: individuals accused or even convicted by a Polish court could have simply crossed the border between Poland and another EU Member State in order to avoid prosecution or detention, as other Member States would have been forced to refuse judicial cooperation with Poland.

The EAW works indeed in a fundamentally different way compared to the Dublin asylum system. In the latter context, the Court of Justice concluded in the N.S. case that it is possible to suspend Dublin transfers once systemic problems in a Member State are identified. ${ }^{74}$ There is no need for an additional individual assessment of the specific situation of the applicant, i.e. the second prong of the Aranyosi test. The reason for this is that, under the Dublin system, the Member State that does not transfer an asylum seeker in view of systemic deficiencies in the other Member State simply takes direct responsibility for the assessment of the asylum claim. Under the EAW, on the other hand, Member States in most cases will not be competent to prosecute or detain the individual subject to the warrant: extraterritorial application of substantive national criminal laws remains confined to exceptional cases. EU criminal cooperation based on mutual trust has not changed the dogma of territoriality of criminal law. ${ }^{75}$ This difference between the Dublin and EAW systems was outlined by Advocate General Bot in the Opinion in Aranyosi ${ }^{76}$ and explains why the individual test was added in the context of the EAW: it plays an important role in preventing cases of impunity in the AFSJ.

Furthermore, taking a strict stance in $L M$ would have meant for the Court to assess in abstract the independence of all Polish courts, with the possible result of excluding the Member State and its courts from the European legal space. ${ }^{77}$ Yet, it is evident that some domestic courts, including the Supreme Court itself, are still playing on the side of the Court of Justice and of the rule of law, by challenging domestic laws on the basis of EU law and sending preliminary references to the

\footnotetext{
${ }^{74} \mathrm{CJEU}$, N.S., supra note 45.

${ }^{75}$ Rizcallah (2019).

${ }^{76}$ CJEU, Case C-404/15 Aranyosi, Opinion of Advocate General Bot, ECLI:EU:C:2016:140, in particular paras. 59 and 60 .

${ }^{77}$ Biernat (2018), arguing that such a result would be a 'vote of no confidence' against all Polish courts, despite the fact that many are still fighting for the rule of law and judicial independence.
} 
CJEU. ${ }^{78}$ Excluding them from the European judiciary tout court would have thus prevented this 'bottom up' resistance. ${ }^{79}$ Furthermore, it is at least not so clear that all Polish courts will not be independent in all cases even after the reforms. ${ }^{80}$ There is no doubt that the Polish reforms undermine, threaten, reduce judicial independence; but is it so evident that, after the reforms, all Polish civil and criminal proceedings would not comply with EU or ECHR standards? Finally, the reaction at the political level to a strong intervention of the Court expelling Poland from the European judiciary would have most likely been extremely harsh. Further attacks to the Court of Justice's legitimacy and authority could have been easily expected.

On the other hand, the ruling in Commission v. Poland was much more targeted and precise. The assessment concerned a specific piece of adopted legislation and its negative effects on judicial independence, and not the abstract independence of all domestic courts. ${ }^{81}$ Despite the finding of a breach of Article 19 TEU, there has been no exclusion of Polish courts, including the Supreme Court, from the 'European judiciary' and quite on the contrary, domestic courts-again including the Supreme Court—can still play on the side of the Court of Justice, as they are already trying to do with the preliminary references on the judiciary reforms.

\subsection{The Messages of the Intermezzo}

The $L M$ case was therefore not the most suitable platform for a strong intervention of the Court in the Polish crisis. Yet, the Court still sent a few important messages on the rule of law developments in the country and generally on the EU values' oversight scheme. The first message, as already noted in the previous pages, is the space that is dedicated, and the role that is given, to the Commission's reasoned proposal under Article 7(1) TEU. In the opening paragraphs of the ruling, the Court offered a fairly long summary of the document. The CJEU was not in a position to explicitly endorse those findings, but later it made clear that the reasoned proposal is 'particularly relevant' for the first, 'systemic' prong of the assessment to be

\footnotetext{
${ }^{78}$ See also Spieker (2018), p. 22 on the advantages of keeping Polish courts in the EU legal order and EU law as the 'relevant standard' for cooperation between Member States.

${ }^{79}$ On the role of national courts in fighting 'bottom up' systemic rule of law and fundamental rights deficiencies, see also von Bogdandy et al. (2012).

${ }^{80}$ See also Kosar (2018).

${ }^{81}$ This still has challenges: while it is true that the Court has often been called to adjudicate on the 'independence' of national courts, it did so in a very different context, namely that of Article 267 TFEU, where the Court examines the independence of specific bodies that sent a preliminary reference to Luxembourg. The Court is therefore called upon to develop clearer and perhaps more stringent criteria, something that is not easy to do in view of the differences between Member States in understanding and realizing judicial independence: see Kosar (2018).
} 
conducted by domestic courts. ${ }^{82}$ In doing so, it gave some legal bite to what would otherwise be only a political document.

Secondly, the Court underlined the relevance of the principle of judicial independence for the Union's legal order. It held that judicial independence is 'part of the essence of the fundamental right to a fair trial', a fundamental right that is in turn of 'cardinal importance' as it contributes to guaranteeing all other rights deriving from EU law as well as safeguarding the values of Article 2 TEU. ${ }^{83}$ Having summarized its approach to judicial independence as having an internal and external aspect, the Court developed in particular a few aspects relating to rules on dismissal of members ${ }^{84}$ and on disciplinary regimes, where the Court held that rules must 'display the necessary guarantees in order to prevent any risk of its being used as a system of political control of the content of judicial decisions'. ${ }^{85}$ By doing so, the Court clarified its standards for the following cases, and then punctually applied them in the following ruling on the Supreme Court. ${ }^{86}$

There is then a final aspect of the $L M$ decision worth highlighting, namely the Court's attention to the political mechanisms available to safeguard EU values. The Court seems to well understand that ensuring democracy or the rule of law is not a task of judicial actors only. ${ }^{87}$ In the first place, as already noted several times, the Court gave crucial relevance to the Commission's reasoned proposal under Article 7 TEU. Second, in confirming the second prong of the Aranyosi test, the Court held that the competence to generally suspend the application of the EAW in a Member State belongs only to the Council and the European Council. The Court reached this conclusion on the basis of recital 10 of the EAW Framework Decision, which affirms that the implementation of the EAW system 'may be suspended only in the event of a serious and persistent breach by one of the Member States of the principles set out in Article 6(1) EU, determined by the Council pursuant to Article 7(1) EU with the consequences set out in Article 7(2) thereof'. The recital was adopted before the Nice Treaty amendments to the Article 7 system and has never been modified since then, thus it does not mention the preventive mechanism now contained in Article 7 (1) and still refers to 'Article 6' (now Article 2) and to the 'Council' (now the 'European Council'). In $L M$, the Court decided to judicially update the references contained in the recital and read it as requiring first a determination of the European Council under what is now Article 7(2) TEU, and then a decision of the Council on the suspension of the EAW. ${ }^{88}$ Once this second decision is taken, judicial authorities 'would be required to refuse automatically to execute any European arrest warrant

\footnotetext{
${ }^{82}$ See CJEU, LM, supra note 1, para. 61.

${ }^{83}$ See CJEU, LM, supra note 1, para. 48.

${ }^{84}$ CJEU, LM, supra note 1, para. 66.

${ }^{85} \mathrm{CJEU}$, LM, supra note 1, para. 67.

${ }^{86} \mathrm{CJEU}$, Commission v. Poland, supra note 69, paras. $73-77$, which include several references to the $L M$ case.

${ }^{87}$ See also Avbelj (2018).

${ }^{88} \mathrm{CJEU}$, LM, supra note 1, paras. 70-71.
} 
issued by the Member State concerned, without the need to conduct an individual assessment'. ${ }^{89}$

The Court is thus respectful of the political procedures created by the Treaties and of the Council's decision to make a general suspension of the EAW possible only after a decision of the European Council. The system, as it stands, might be disappointing: it is now evident how difficult it is to reach a decision under Article 7(1) TEU, let alone a unanimous decision under Article 7(2) TEU. But the Court could have hardly reconciled a different reading with the explicit text of recital 10 of the EAW Framework Decision. ${ }^{90}$ It would rather be for the legislator to modify the preamble of the EAW and more broadly for the political institutions to rethink and reform EU oversight mechanisms. A centralized monitoring scheme seems in fact needed to prevent fragmentation, ${ }^{91}$ i.e. the risk that different courts of different Member States reach conflicting decisions on the very existence of systemic threats, and consequently on EAW or Dublin transfers. ${ }^{92}$ Yet, it is not the task of the Court to create such a scheme.

Ultimately, the Court's approach to the political mechanisms is not only textually, but also systematically convincing. First, the solution to the constitutional crises of Poland and Hungary is not in the hands of the Court of Justice alone. Problems originating in the political sphere simply cannot be addressed only with legal decisions and ruling ${ }^{93}$ they require a political reaction. ${ }^{94}$ Second, it should not be forgotten that the EU Treaties themselves leave space for the 'political game' when it comes to the protection of EU values. Most importantly, they do so when they exclude the Court from substantive deliberations under Article 7 TEU. ${ }^{95}$ Hence, while it is true that the Court cannot simply leave all responsibilities to political authorities, it should not completely replace them, nor the procedures created by the Treaties.

\footnotetext{
${ }^{89} \mathrm{CJEU}$, LM, supra note 1, para. 72.

${ }^{90}$ For a different view, see Bard and van Ballegooij (2018), arguing that the Court should have reinterpreted the preamble of EAW and concluded that the system could be suspended even after a decision under Article 7(1) or perhaps the mere activation of it.

${ }^{91}$ See Lazowski (2018) on how the Aranyosi approach might threaten the uniform application of EU law.

${ }^{92}$ On the need for a more centralized assessment, see Wendel (2019) and Bard and van Ballegooij (2018).

${ }^{93}$ And the same is true if we conceive the rule of law crisis as a crisis of trust, see von Bogdandy (2018), pp. 689-690: 'It is inconsistent to diagnose a crisis in trust, but to expect the relevant legal instruments to overcome it, as do some legal analyses of the Commission's "rule of law framework" ... A crisis in trust cannot be "resolved" by legal instruments, it can only be hedged and gradually allowed to subside over time.'

${ }^{94}$ See e.g. Besselink (2017); see also Kosar (2018), pointing out that ultimately the Polish elections might be more important than any Court of Justice's intervention for safeguarding judicial independence in the country.

${ }^{95}$ See Article 269 TFEU.
} 


\section{Conclusion}

When read in the broader context described in this chapter, the $L M$ case can hardly be understood as a general signal of the Court's reluctance to engage with the Polish rule of law crisis. On the contrary, the Court has shown a proactive approach by redirecting the ASJP case from austerity to the rule of law, interpreting Article 19 TEU in an exceptionally broad manner, and thus creating a new tool to enforce judicial independence across the Union. The Commission and the Court immediately exploited the new tool in the infringement action on the Supreme Court. These were the two key acts of the Court's rule of law play and, measured against them, the $L M$ decision loses the centrality it was expected to have.

Although there are some not entirely convincing steps in the Court's reasoning and outcome, ${ }^{96}$ the approach of the Court was ultimately a balanced one: it maintained the need for the individual prong of the Aranyosi test, but left the national court a fairly wide opportunity to refuse referral were it to consider that, in the specific case, the individual suffered a real risk of unfair trial; ${ }^{97}$ furthermore, in reaching its decision, the Court also signaled its broad concerns with the rule of law in Poland. The framing of the case, however, did not offer the best opportunity to take a strong stance on the Polish crisis and a broad reformulation of the questions referred could have easily led to accusations of judicial activism, especially after the already creative and groundbreaking decision of $A S J P{ }^{98}$ The lesson $L M$ seems to teach is that infringement procedures seem to be better suited than 'horizontal' attempts to protect EU values, ${ }^{99}$ also considering that mutual trust creates complex problems of a federal and constitutional nature that the Court always needs to take into account. ${ }^{100}$ Questions of judicial independence and rule of law are in fact to be addressed in a systemic manner, as it can be done in Commission's infringement actions against violations of Article 19 TEU; on the other hand, it is harder for horizontal preliminary references, based on the protection of individual fundamental rights, to frame the case in the most appropriate manner. ${ }^{101}$ The positive impact that well-conducted infringement procedures may have has been further shown by the decisions of the Court in the first Commission v. Poland case on the reform of the Supreme Court. This was arguably the first true victory of the EU institutions after several unsuccessful attempts to fight against Polish constitutional backsliding. The forthcoming decisions on the second infringement actions, as well as on the preliminary references raised by Polish courts, offer now further opportunities to safeguard

\footnotetext{
${ }^{96}$ See Sect. 2 above.

${ }^{97}$ As noted above, however, the national court ultimately rejected the appeal of Mr. Celmer: see Irish High Court, supra note 31.

${ }^{98}$ For a different view, see Krajewski (2018) and Wendel (2019).

${ }^{99}$ On 'horizontal' enforcement, see Canor (2013).

${ }^{100}$ Wendel (2019).

${ }^{101}$ Sonnevend (2018).
} 
judicial independence. After the $L M$ intermezzo, we are therefore in the truly decisive act of the rule of law play between the EU and Poland.

\section{References}

Avbelj M (2018) We still haven't found what we're looking for. Verfassungsblog, www. verfassungsblog.de/we-still-havent-found-what-were-looking-for/

Bard P, van Ballegooij W (2018) Judicial independence as a precondition for mutual trust? The CJEU in Minister for Justice and Equality v. LM. New J Eur Crim Law 9:3

Batory A (2016) Defying the commission: creative compliance and respect for the rule of law in the EU. Public Adm 94:3

Belavusau U (2013) On age discrimination and beating dead dogs: Commission v. Hungary. Common Market Law Rev 50:4

Besselink L (2017) The Bite, the Bark and the Howl: Article 7 TEU and the rule of law initiatives. In: Jakab A, Kochenv N (eds) The enforcement of EU law and values. Oxford University Press, Oxford, pp 128-144

Biernat S (2018) How to assess the independence of Member State Courts? Verfassungsblog, www. verfassungsblog.de/how-to-assess-the-independence-of-member-state-courts/

Biernat S, Kawczyńska M (2018) Though this be madness, yet there's method in't: pitting the Polish constitutional tribunal against the Luxembourg Court. Verfassungsblog, www. verfassungsblog.de/though-this-be-madness-yet-theres-method-int-the-application-of-the-prose cutor-general-to-the-polish-constitutional-tribunal-to-declare-the-preliminary-ruling-proce dure-unconstitut/

Bonelli M, Claes M (2018) Judicial serendipity: how Portuguese judges came to the rescue of the Polish judiciary. Eur Const Law Rev 14:3

Broberg M, Fenger N (2014) Preliminary references to the European Court of Justice. Oxford University Press, Oxford

Canor I (2013) My Brother's Keeper? horizontal Solange: ‘An Ever Closer Distrust among the Peoples of Europe'. Common Market Law Rev 50:2

Dawson M, Muir E (2013) Hungary and the Indirect protection of EU fundamental rights and the rule of law. German Law J 14:10

Halmai G (2017) The early retirement age of the Hungarian Judges. In: Nicola F, Davies B (eds) EU law stories - contextual and critical histories of European jurisprudence. Cambridge University Press, Cambridge, pp 471-488

Konstadinides T (2019) Judicial independence and the rule of law in the context of non-execution of a European Arrest Warrant: $L M$. Common Market Law Rev 56:3

Kosar D (2018) The CJEU has spoken out, But the show must go on. Verfassungsblog, www. verfassungsblog.de/the-cjeu-has-spoken-out-but-the-show-must-go-on/

Krajewski M (2018) Who is afraid of the European Council? The Court of Justice's cautious approach to the independence of domestic judges. Eur Const Law Rev 14:4

Lazowski A (2018) The sky is not the limit: mutual trust and mutual recognition aprés Aranyosi and Căldăraru. Croat Yearb Eur Law Policy 14:1-30

Markakis M, Dermine P (2018) Bailouts, the legal status of memoranda of understanding, and the scope of application of the EU Charter: Florescu. Common Market Law Rev 55:2

Pech L, Scheppele KL (2017) Illiberalism within: rule of law backsliding in the EU. Camb Yearb Eur Legal Stud 19:3-47

Pech L, Wachowiec P (2018) 1095 days later: from bad to worse regarding the rule of law in Poland (Part II). Verfassungsblog, www.verfassungsblog.de/1095-days-later-from-bad-to-worseregarding-the-rule-of-law-in-poland-part-ii/ 
Rizcallah C (2019) The challenges to trust-based governance in the European Union: assessing the use of mutual trust as a driver of EU integration. Eur Law J 25:1

Sadurski W (2019) Poland's constitutional backsliding. Oxford University Press, Oxford

Scheppele KL (2018) Rule of law retail and rule of law wholesale: the ECJ's (Alarming) 'Celmer' decision. Verfassungsblog, www.verfassungsblog.de/rule-of-law-retail-and-rule-of-law-whole sale-the-ecjs-alarming-celmer-decision/

Sonnevend P (2018) A clever compromise or a tectonic shift? The LM judgment of the CJEU. Verfassungsblog, www.verfassungsblog.de/a-clever-compromise-or-a-tectonic-shift-the-lmjugment-of-the-cjeu/

Spieker LD (2018) From moral values to legal obligations - on how to activate the Union's common values in the EU rule of law crisis. MPIL Research Paper Series No. 2018-24

Uitz R (2019) The perils of defending the rule of law through dialogue. Eur Const Law Rev 15:1

von Bogdandy A (2018) Ways to frame the European rule of law: Rechtsgemeinschaft, trust, revolution, and Kantian Peace. Eur Const Law Rev 14:4

von Bogdandy A, Kottmann M, Antpöhler C, Dickschen J, Hentrei S, Smrkolj M (2012) Reverse Solange - protecting the essence of fundamental rights against EU Member States. Common Market Law Rev 49:2

von Bogdandy A, Bogdanowicz P, Canor I, Taborowski M, Schmidt M (2018) Guest editorial: a potential constitutional moment for the European rule of law - the importance of red lines. Common Market Law Rev 55:4

Wendel M (2019) Mutual trust, essence and federalism - between consolidating and fragmenting the area of freedom, security and justice after $L M$. Eur Const Law Rev 15:1

Matteo Bonelli is an assistant professor in European law at the Faculty of Law of Maastricht University, the Netherlands.

Open Access This chapter is licensed under the terms of the Creative Commons Attribution 4.0 International License (http://creativecommons.org/licenses/by/4.0/), which permits use, sharing, adaptation, distribution and reproduction in any medium or format, as long as you give appropriate credit to the original author(s) and the source, provide a link to the Creative Commons license and indicate if changes were made.

The images or other third party material in this chapter are included in the chapter's Creative Commons license, unless indicated otherwise in a credit line to the material. If material is not included in the chapter's Creative Commons license and your intended use is not permitted by statutory regulation or exceeds the permitted use, you will need to obtain permission directly from the copyright holder.

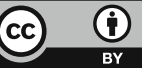

